\title{
Factors Influencing Interoperability Level Required for the Implementation of T-Government in Saudi Arabia
}

\author{
Sameer Alshetewi ${ }^{1}$, Fahad Alturise ${ }^{2} \&$ Faten Karim $^{3}$ \\ ${ }^{1}$ Ministry of Defence, Riyadh, Saudi Arabia \\ ${ }^{2}$ College of Science and Arts, Computer Science Department Qassim University, Ar Rasa, Saudi Arabia \\ ${ }^{3}$ College of Computer and Information Sciences, Princess Nourah bint Abdulrahman University, Riyadh, Saudi \\ Arabia
}

Correspondence: Sameer Alshetewi, Ministry of Defence, Riyadh, Saudi Arabia. E-mail: s.alshetewi@moda.gov.sa

Received: February 9, 2018

Accepted: February 28, 2018

Online Published: April 25, 2018

doi:10.5539/cis.v11n2p40

URL: http://dx.doi.org/10.5539/cis.v11n2p40

\begin{abstract}
Governments around the world have invested significant sums of money on Information and Communication Technology (ICT) to improve the efficiency and effectiveness of services being provided to their citizens. However, they have not achieved the desired results because of the lack of interoperability between different government entities. Therefore, many governments have started shifting away from the original concept of e-Government towards a much more transformational approach that encompasses the entire relationship between different government departments and users of public services, which can be termed as transformational government ( $t$ Government). This implementation of t-Government requires a high level of interoperability between government organisations. In this paper, a model is proposed to explore and investigates the key factors that influence interoperability required for the implementation of $\mathrm{t}$-Government in Saudi Arabian context from four key areas, namely, organisational, technological, political and social using institutional theory as a lens. This model was developed comprising the effect of six main constructs: technological compatibility, organizational compatibility, governance readiness, citizen centricity and e-Government program on interoperability required for the implementation of t-Government. The model factors, relationships, and hypotheses stemmed from the literature on Information Sharing, Information Integration, G2G, interoperability and t-Government models.

The results show that technological compatibility, organizational compatibility, and governance readiness have a positive impact on the interoperability required for the implementation of t-Government in this particular context. Unexpectedly, it indicates that citizen centricity has negative impact on the interoperability required for the implementation of t-Government. It also shows that there is a direct and positive impact from e-Government program (Yesser) to technological compatibility and governance readiness. Moreover, it shows that there is a direct and positive impact from citizen centricity to e-Government program (Yesser). Unexpectedly, the results indicate that e-Government program (Yesser) has no impact on the interoperability required for the implementation of $t$ Government. It also indicates that the e-Government program (Yesser) doesn't affect organizational compatibility.

This paper provides a model for creating interoperability between government organisations to help e-Government officials and policy makers to identify the key factors that can affect the interoperability level required for the implementation of t-Government, and examines how these issues could be treated in practice. It also provides a guideline to researchers with regard to the impact of these identified factors on interoperability required for tGovernment implementation.
\end{abstract}

Keywords: e-Government, Interoperability (IOP), t-Government.

\section{Introduction}

Governments around the world are currently focus on interoperating existing services in order to create ease of access and improvements in service (Weerakkody \& Dhillon, 2008). The recent United Nations e-Government Surveys (UnitedNations, 2012, 2014) results found that many nations have put in place e-Government applications to enhance the efficiency of the public sector and streamline government systems. In addition, the report highlights the importance of placing a greater emphasis on creating connections between different government departments 
in order to create further efficiencies and states that this should be the goal of a transformational government (tGovernment).

Nowadays, the concept of a transformational government (t-Government) needs to be viewed on an international scale. In order to facilitate more centrally-connected and citizen-centric e-Government services, and put the needs of individuals and businesses at the center of online processes, many governments have started shifting away from the concept of e-Government towards a much more transformational approach towards the entire relationship between different government organisations and users of public services (A. M. Al-Khouri, 2011; Alshetewi, Goodwin, Karim, \& de Vries, 2015).

t-Government remains in its early stages. It is also the most challenging phase to fully comprehend. It is a complex endeavour because it needs the interrelation of information systems, public e-Services, departments and organisations, policy constraints and regulations (Klievink \& Janssen, 2010; Su et al., 2011). This is called interoperability (IOP). Interoperability (IOP) is recognized as a key determinant and principle for e-Government maturity and development (Pardo, Nam, \& Burke, 2011; Sarantis, Charalabidis, \& Psarras, 2008), and the IOP model has been the tools for implementing this determinant. However, governments are far from interoperability. They face difficulty in attaining IOP among their information systems (Landsbergen $\mathrm{Jr}$ \& Wolken Jr, 2001; Tambouris \& Tarabanis, 2005). The lack of IOP has been a major challenge to e-Government maturity (Gottschalk, 2009a; Lam, 2005a; UnitedNations, 2014). According to Pardo et al. (2011), IOP is a means and not an end in itself. It has central importance to e-Government efforts to improve government operations and provide services to citizens. There is a clear need to create a novel approach such as e-Government IOP within government organisations to achieve t-Government (Irani, 2007). As Watmore says (Irani, 2007) "t-Government is an end in itself and not a means to an end".

Many, if not most, models and frameworks do not reflect the complex grid of interwoven technical, organisational, political and social issues and constraints involved. Hence, integration and interoperation projects in e-Government run a high risk of failure (Scholl \& Klischewski, 2007). This paper developed a model stemmed from the literature on Information Sharing, Information Integration, G2G, interoperability and t-Government models to explore the key factors that affect the IOP between government organisations to facilitate the implementation of t-Government within the Saudi Arabian context using institutional theory as a lens.

The remainder of the paper is structured as follows: Section 2 discusses on the factors influencing IOP for tGovernment implementation. The methodology used to test the proposed model, and the analysis result are presented in Section 3. The synthesis of the empirical findings are presented in Section 4. The conclusions, limitations and future recommendations are presented in Section 5.

\section{Factors Influencing IOP for t-Government Implementation.}

As we mentioned in the Introduction section, the existing literature on e-Government has failed to present a comprehensive framework or model of IOP required for the implementation of t-Government. Therefore, this paper attempt to identify all of the constructs from literature review on Information Sharing, Information Integration, $\mathrm{G} 2 \mathrm{G}$, interoperability and t-Government models in conjunction with the institutional theory as a lens. Literature indicates many factors and barriers influence e-Government IOP required for the implementation of t-Government. Therefore, it is important to understand which of those factors, barriers, and issues are effectively relevant to IOP initiatives in the context of Saudi Arabia. Chandler and Emanuels (2002) pointed out, that e-Government implementation is a long-term project and has many challenges and barriers, and understanding of these factors will protect governments from the risk of failure (A. Al-Khouri \& Bal, 2007). Researches on the implementation of information systems in government organizations more often focuses on success factors (Rosacker \& Olson, 2008; Somers \& Nelson, 2001). Therefore, this paper focuses on the success factors to develop this e-Government IOP model (illustrated in the Appendix).

This model featuring six unique constructs-each construct represents a single theoretical variable of interest. The model hypothesises upon how Technological Compatibility (TC), Organisation Compatibility (OC), Governance Readiness (GR), e-Government program (Yesser) (EG), and Citizen Centricity (CC) influence the IOP for tGovernment implementation (TG).

This model assumes that the required IOP level for the implementation of t-Government will be influenced by technological compatibility. Technological compatibility refers to the compatibility of the information technologies required for creating IOP between government organisations to facilitate the implementation of tGovernment. Compatibility is a technological property of system components enabling two components to work, act or go together. According to Landsbergen Jr and Wolken Jr (2001), technological compatibility will always be an important consideration when establishing interoperability. By analysing this construct, insight will be gained 
into what will be required for the implementation of t-Government (Soliman, Affisco, Affisco, \& Soliman, 2006). Researchers tend to hold different opinions as to the most effective means of classification for technological compatibility issues. For the purpose of this study, technological compatibility factors focus on those matters which affect the integration between government organisations and the implementation of t-Government such as: (a) Standards, (b) Architecture Interoperability, (c) Data requirements and (d) Back office systems (The appendix explains these factors and their dimensions in detail). Depending on the previous arguments, this model proposes:

H1: Technological Compatibility factors positively influence the level of IOP required for the implementation of t-Government.

Organisational issues represent a significant factor in the implementation of t-Government (Weerakkody \& Dhillon, 2008). Consequently, organisational compatibility must be thoroughly understood, and any inherent difficulties overcome before achieving its satisfactory adoption (Soliman et al., 2006). Organisational compatibility refers to the organisation changed required for creating IOP between government organisations to facilitate the implementation of t-Government. Researchers' opinions vary as to how organisational compatibility issues should be classified, but for the purposes of this study, organisational compatibility factors will relate to the ability of government organisations to interoperate and implement t-Government. Thus within these parameters, it will involve: (a) technical staff, (b) organisational structure, and (c) business process management (The appendix explains these factors and their dimensions in detail). Depending on the previous arguments, this model proposes:

H2: Organisational Compatibility factors positively influence the level of IOP required for the implementation of t-Government.

Governance Readiness in e-Government is closely linked with the political context as success depends on the level of commitment and innovative vision shown by politicians (Heeks \& Stanforth, 2007). Therefore support from government is necessary to create the appropriate levels of IOP required for the implementation of t-Government. According to Lynn, Heinrich, and Lynn Jr (2000) "governance refers to the means for achieving direction, control and coordination of wholly or partially autonomous individuals or organizations on behalf of interests to which they jointly contribute" $(2000$, p. 235$)$. In referring to public policies and their implementation, he defines governance "as regimes of laws, administrative rules, judicial rulings, and practices that constrain, prescribe and enable government activity, where such activity is broadly defined as the production and delivery of publicly supported goods and services" (2000, p. 235). For the purposes of this research, governance readiness concerned about principles, roles, responsibilities, and compliance strategies to build a comprehensive planning to clarify the roles and responsibilities of all government organizations to mitigate technology incompatibility and resistance change invest in scalable strategies and enhance the level of IOP required for the implementation of t-Government. It includes: (a) strategies and regulations, (b) leadership, (c) fund, and (d) stakeholders (The appendix explains these factors and their dimensions in detail). Depending on the previous arguments, this model proposes:

H3: Governance Readiness factors positively influence the level of IOP required for the implementation of $t$ Government.

The implementation of t-Government requires that technology investments and service transformation must be directed towards the citizen need (Irani, 2007). This requires a shift from organisation-centric operations, to a more citizen-focused approach (Themistocleous, Irani, \& Love, 2005). Citizen Centricity has been identified as a critical success factor for the implementation of t-Government, which means that IOP among public organisations becomes imperative (Janssen \& Scholl, 2007; Themistocleous et al., 2005). t-Government implementation is about government organisations availing themselves of the latest in technological advances in order to better serve the citizens. It requires cooperation between government organisations in order to provide seamless more accessible, citizen-focussed government services (Al-Sebie \& Irani, 2005; Irani, 2007; Weerakkody \& Dhillon, 2008). Therefore, the focus should be on citizens' needs and the delivery of services that add value to the citizen (Lindquist, 2013; PWC, 2012; UnitedNations, 2014). Also, governments tend to use social media to meet citizen need. First, the public is already very familiar with social media platforms such as Facebook and Twitter and these platforms provide an opportunity for government organisations to relay on them without setting up their own platforms. Second, these are cost efficient as social media initiatives do not require high investment costs, as they typically ride on commercial and non-governmental platforms. Once these tools are in place, governments can also consult on sectoral issues that affect the quality of life of their people (UnitedNations, 2014). This is a step beyond the simple provision of information, described above. In a similar vein, governments can learn to use social media as a tool to collect and take into account people's views and feedback. Citizen centricity is measured in this study by: citizen centric focus, citizen needs, citizens satisfaction, and citizens familiarity (The appendix explains these factors and their dimensions in detail). Hence, there is a causal link between citizen centricity and IOP required 
for the implementation of t-Government. The following hypothesis was proposed:

H4: Citizens Centricity positively influences the level of IOP required for the implementation of t-Government.

During the last few years, facing increasing demands on IOP and integration to implement t-Government, central governments around the world have started initiatives to provide comprehensive frameworks in order to provide guidance to activities on the local and regional level and to prevent investments which do not contribute to IOP (Klischewski, 2004). This engagement supports the implementation of t-Government through a thoroughly developed plan (Irani, 2007). According to Weerakkody and Dhillon (2008), "central government departments are endeavouring to work with each other to deliver better services to citizens via a one-stop-shop environment for all services under the guise of electronic government (e-Government)". Reddick (2005), in his analysis of the evolution of e-Government adoption identifies the central government as the supply side perspective which is responsible for governance, provision, and services delivery. In the context of Saudi Arabia, the central government is operated by e-Government program (Yesser). This program (Yesser) operates as facilitator, enabler, and motivator for e-Government implementation in the public sector through the establishment of various initiatives and products. After reviewing the role of Yesser in implementing e-Government (Yesser, 2015a), there are important factors should be considered in this research to measure the impact of e-Government program (Yesser) on the IOP required for the implementation of t-Government such as: integration to Yesser, Government Service Bus (GSB), Government Security Network (GSN), Single Sign On (SSO), National Enterprise Architecture (NEA), and the Saudi portal (Yesser, 2015a) (The appendix explains these factors and their dimensions in detail).

Hence, there is a causal link between the e-Government program (Yesser) and the IOP required for the implementation of $\mathrm{t}$-Government. The following hypothesis was proposed:

H5: e-Government program (Yesser) positively influences the level of IOP required for the implementation of tGovernment.

Yeseer has provided many technical initiatives that should lead to the development of e-Government in Saudi Arabia and facilitate the integration between government organisations. In addition, Yesser has been established to enable organisations to build a reliable infrastructure that facilitates the implementation of e-Government and enables data to be exchanged between government organisations by improving the back-office performance of organisations. Yesser also helps government organisations to standardize the work processes inside the agency by presenting standards for the specifications of e-Government systems. Furthermore, the Yesser program has developed many strategies and regulations, mission, and visions to support e-Government implementation. Moreover, e-Government program (Yesser) was created to increase the productivity of government organisations to provide e-Government services to their citizens in a simple and appropriate way (Yesser, 2015a).

One of the objectives of creating Yesser was to provide better, more convenient, and more seamlessly integrated e-Government services for citizens. Yesser began promoting citizen-centric services by providing e-Services via the Saudi Arabian government national portal by integrating with other government organisations and through links to their websites to enable citizens access e-Services anytime from anywhere through the Internet. This approach was chosen as the best way to enable government services in an efficient manner. This is a clear indication that there is a significant impact from citizen centricity on the e-Government program (Yesser, 2015a). Drawing a conclusion from the above arguments, we propose here:

H6: Citizen Centricity positively influences the e-Government programme (Yesser).

H7: The e-Government programme (Yesser) positively influences Technological compatibility.

H8: The e-Government programme (Yesser) positively influences Organisational compatibility.

H9: The e-Government programme (Yesser) positively influences Governance readiness.

\section{Methodology}

Web-based structured questionnaire data were collected from government organisations in Saudi Arabia (217 usable responses). To clarify the relationships among these constructs, a structural equation model (SEM) is utilised to examine the model fit with these nine hypotheses.

\subsection{Data Collection}

To achieve the stated objectives, a conceptual model was hypothesized and empirically tested using data derived from web-based questionnaires. Six constructs were used for the purposes of evaluating the factors that influence interoperability required for the implementation of t-Government in Saudi Arabian context. Data was obtained through a web-based survey of 166 government organisations in Saudi Arabia from December 2013 to April 2014. A six-point Likert scale questions were used to collect data for each of the six constructs. The scale used offered 
the following possible responses: (1) Strongly Agree; (2) Agree; (3) Somewhat agree; (4) Somewhat disagree; (5) Disagree; and (6) Strongly disagree.

\subsection{Measurement Scales Used in the Study}

The questionnaire data were analysed using multivariate statistics. First, Exploratory Factor Analysis (EFA) to uncover the number of factors that underlay the set of items in each model construct conceptually and statistically. Second, Confirmatory Factor Analysis (CFA) to provide a foundation for subsequent model assessment and refinement. Structural Equation Modelling (SEM) then to examine the research hypotheses (Hair, 2010). SEM comprises of two models, a measurement model and a structural model. The measurement model is concerned with how well various exogenous variables measure latent variables. The structural model (SM) on the other hand analyse the inter-relationships between the constructs of the hypothesized model. To analyse this data, AMOS (analysis of moment structures) Version 22 and SPSS Version 22 were used.

Prior to conducting these multivariate statistical analyses, an examination of the data and scale reliability were conducted. This determines if they meet the basic assumptions required for further analysis (Byrne, 2013; Hair, 2010). This project used Cronbach's alpha, a measure of reliability that provides an indication of the response consistency across items. The reliability measures in terms of Cronbach's alpha as shown in (Table 1) were above the recommended level of 0.70 as an indicator for adequate internal consistency (Hair, 2010).

Table 1. Constructs Cronbach's Alpha

\begin{tabular}{llll}
\hline Constructs & Number of cases & Number of variables & Cronbach's alpha $(\boldsymbol{\alpha})$ \\
\hline TC & 217 & 18 & 0.864 \\
\hline OC & 217 & 12 & 0.807 \\
\hline GR & 217 & 21 & 0.816 \\
\hline CC & 217 & 4 & 0.797 \\
\hline EG program (Yesser) & 217 & 6 & 0.887 \\
\hline IOP for TG & 217 & 3 & 0.920 \\
\hline
\end{tabular}

\subsection{Data Analysis and Results}

First, an exploratory factor analysis (EFA) using principal component analysis (PCA) with the Varimax orthogonal rotation was performed with SPSS 22.0 on the six constructs to determine which observable variables load on which latent variables, and to confirm its current structure or rearrange them for suitable SEM procedure. Factor loadings are considered to be very significant if these are 0.50 (Hair, 2010). Appropriateness of factor analysis is tested using two important measures. The first measure is Kaiser-Meyer-Olkin (KMO) overall measure of sampling adequacy, and its value was 0.771 which falls within the acceptable limit and was also significant at 1 per cent level of significance as $\mathrm{p} 0.000$. These factor solutions were supported by the cumulative percentage of the variance extracted from these constructs, which ranged from 65.589 to $86.726 \%$. This measure indicates a highly significant correlation among the constructs in the survey. The Cronbach's alpha coefficients of all scales were high and well above the 0.70 threshold level, ranging from 0.797 to 0.920 , demonstrating internal consistency. The constructs (technological compatibility (TC), organisational compatibility (OC), governance readiness (GR), citizen centricity (CC), EG program and IOP for TG implementation) are represented respectively by four, three, four, one, one and one factor/s. This is summarised in (Table 2).

Table 2. EFA Summary Results

\begin{tabular}{|c|c|c|c|c|c|}
\hline Construct & Variable(s) removed & $\begin{array}{l}\text { Factor(s) } \\
\text { extracted }\end{array}$ & $\begin{array}{l}\text { Cronbach's } \\
\text { alpha }\end{array}$ & $\begin{array}{l}\text { Cumulative } \\
\text { variance }\end{array}$ & Factor description \\
\hline $\mathrm{TC}$ & (S_2, A_1, A_5, D_4, BA_1) & 4 & 0.905 & 86.726 & $\begin{array}{l}\text { TC1: standards (4 variables) } \\
\text { TC2: architecture (3 variables) } \\
\text { TC3: data requirements (3 } \\
\text { variables) }\end{array}$ \\
\hline
\end{tabular}




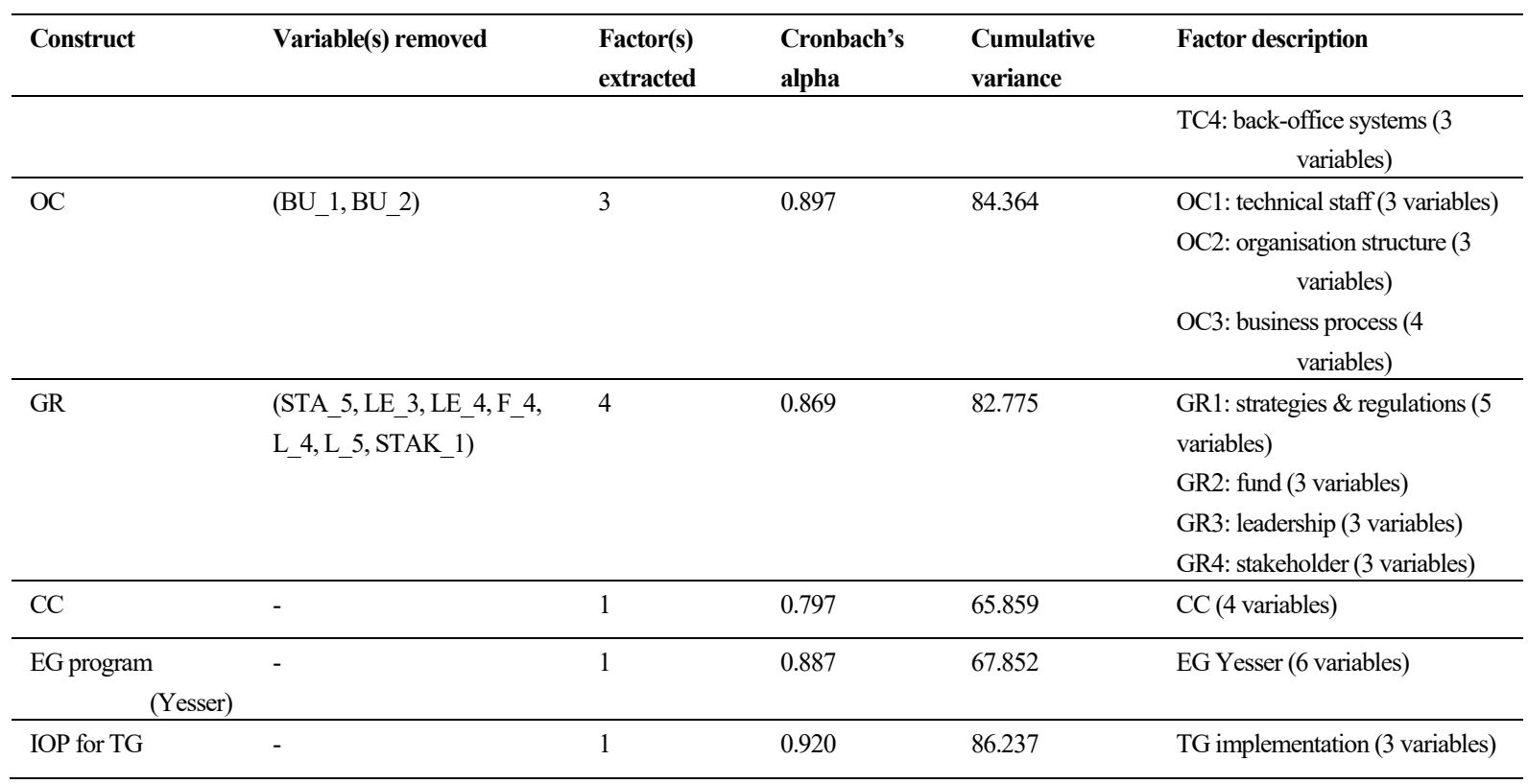

A confirmatory factor analysis was conducted for this model to examine the models identification. The key feature of CFA is its ability to determine how well the specified factor model represents the data. This can be done by examining the model fit indices. If the fit indices prove suitable, the model is accepted. However, a model with unsatisfactory fit indices will usually be re-specified to improve the model fit (Hair, 2010). Various measurement fit indices can assess the model fit. This study chose three absolute fit indices: the goodness-of-fit index (GFI), the root mean square error of approximation (RMSEA), and the standardised root mean residual (SRMR). It also uses two incremental fit measures: the comparative fit index (CFI) and the Tucker-Lewis index (TLI). It uses the ratio of X2 to degree of freedom (X2/df) to evaluate parsimonious fit index (Elsheikh, 2012) (see Table 3).

Table 3. The Goodness of fit measures

\begin{tabular}{llll}
\hline Category & GOF index & Acceptable GFI levels & References \\
\hline Absolute fit indices & GFI & $\geq .90$ indicates a good model fit & Hair et al. (2010); Kline (2011) \\
\cline { 2 - 4 } & RMSEA & $<.08$ indicates a reasonable fit; & Hair et al. (2010) \\
\cline { 2 - 4 } & SRMR & $\leq .08$ indicates a good model fit & Kline (2011) \\
\hline Incremental fit indices & CFI & $\geq .90$ indicates a good fit & Kline (2011) \\
& & & Hair et al. (2010) \\
\cline { 2 - 4 } & TLI & $\geq 0.90$ indicates a good model fit & Kline (2011) \\
& & & Hair et al. (2010) \\
\hline Parsimony fit indices & X2/df & $<3.0$ indicates a good model fit & Kline (2011) \\
& & & Hair et al. (2010) \\
\hline
\end{tabular}

The overall fit measures of the measurement model indicate an adequate fit of the model to the data. $(\mathrm{GFI}=0.910$; RMSEA $=0.029 ;$ SRMR $=0.053 ; \mathrm{TLI}=0.979 ; \mathrm{CFI}=0.982 ;$ and $\mathrm{X}^{2} / \mathrm{df}=1.180$ ). All the indicators (factors) had significant loadings greater than $0.50(\mathrm{p}<0.001)$ on their respective constructs, with the exception of GR4 (funds): this was lower than 0.50 . Next section discusses this issue in more detail. All the constructs were shown to have a composite reliability greater than the threshold level of 0.70 and their reliability was greater than the threshold level of 0.50 (Hair, 2010). The correlation coefficients between each pair of factors were less than 0.850 , suggesting adequate discriminant validity. These results indicate that the measurement model possesses substantial convergent validity and uni-dimensionality.

After validating the established measurement model, the next step was to test the SM by testing the hypothesised conceptual model and the relationships between factors. The assessment procedure of the SM included an 
examination of model fit indices and standardised path coefficients to provide a basis upon which to accept or reject the hypothesised relationships. The criteria for the model fit indices adopted in this analysis were similar to those employed in the measurement model assessment. For the hypothesised relationships to be supported, the important test statistic is the critical ratio ( $\mathrm{CR} / \mathrm{t}$-value). This is calculated by dividing the un-standardised regression weight (URW) by its standard error (SE). A t-value higher than +1.96 and probability (P) values less than 0.05 indicate statistical significance at the level of 0.05 (Byrne, 2013).

The overall fit measures of the structural model indicate an adequate fit of the model to the data (GFI $=0.905$; $\mathrm{RMSEA}=0.032 ; \mathrm{SRMR}=0.059 ; \mathrm{TLI}=0.977$; CFI $=0.975$; and $\left.\mathrm{X}^{2} / \mathrm{df}=1.289\right)($ Hair, 2010).

The results of hypotheses testing are given in (Table 4). Six of the hypothesized paths of the structural model are significant, whereas the remainder paths show a lower level of significance. Next section discusses this result in more details.

Table 4. The structural model (SM) results

\begin{tabular}{llll}
\hline Path (hypothesis) & Standardised path coefficient & t-value & Hypothesis testing result \\
\hline H1: TC $\rightarrow$ TG & 0.37 & $4.535^{* * *}$ & Supported \\
H2: OC $\rightarrow$ TG & 0.33 & $4.110^{* * *}$ & Supported \\
H3: GR $\rightarrow$ TG & 0.18 & $2.425^{*}$ & Supported \\
H4: CC $\rightarrow$ TG & -0.13 & $-2.033^{*}$ & Not supported \\
H5: EG $\rightarrow$ TG & 0.12 & 1.709 n.s & Not supported \\
H6: CC $\rightarrow$ EG & 0.23 & $3.222^{* *}$ & Supported \\
H7: EG $\rightarrow$ TC & 0.21 & $2.623^{* *}$ & Supported \\
H8: EG $\rightarrow$ OC & 0.15 & $1.872 \mathrm{n} . s$. & Not supported \\
H9: EG $\rightarrow$ GR & 0.26 & $3.016^{* *}$ & Supported \\
\hline GOF index & Value & Recommended value & \\
\hline GFI & 0.905 & $>0.90$ & $<0.08$ \\
RMSEA & 0.032 & $\leq 0.08$ & $>0.90$ \\
SRMR & 0.059 & $>0.90$ & $<3.0$ \\
CFI & 0.975 & 0.977 &
\end{tabular}

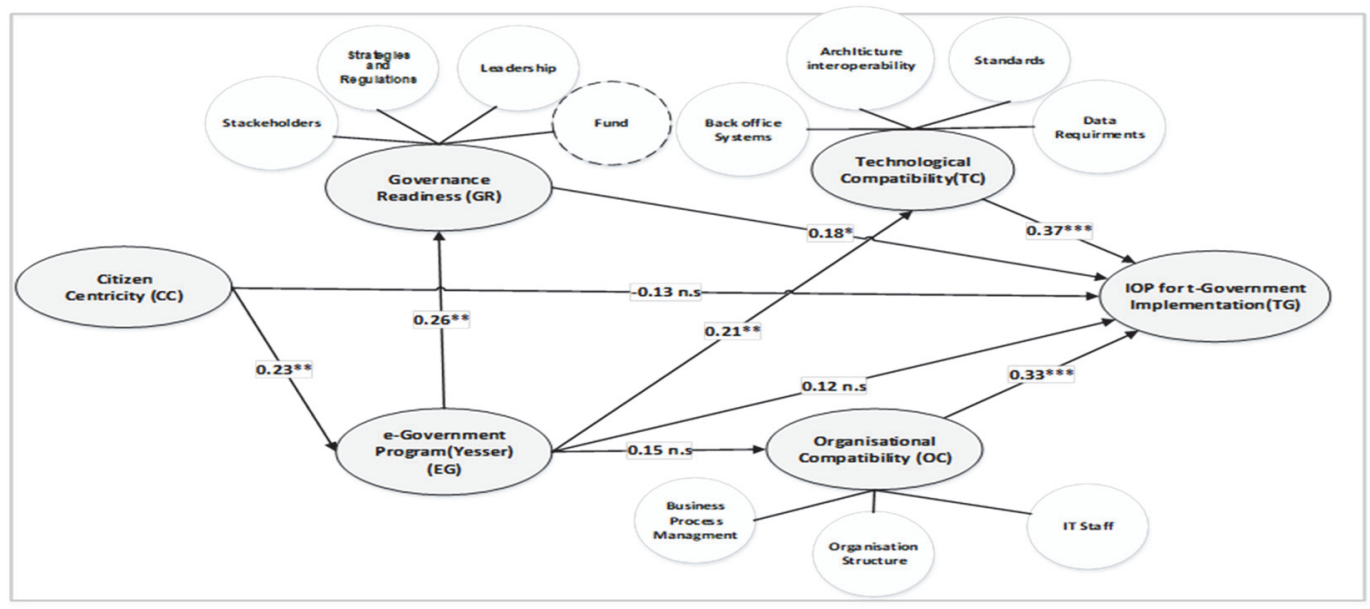

Figure 1. Path Coefficients for the Proposed Structure Model 


\section{Discussion}

This section discusses the results for the proposed model. Nine hypotheses were developed for empirical tesing to be analysed and determine the significant factors regarding IOP level for TG implementation in Saudi Arabia. The core model factors include technological compatibility, organisational compatibility, governance readiness, citizen centricity, and the EG program (Yesser). The next sub-sections discuss the hypotheses and results.

\subsection{The Impact of Technological Compatibility (TC) Factors}

H1: technological compatibility factors positively influence the level of IOP required for TG implementation.

In this study, technological compatibility factors included standards, architecture interoperability, data requirements and back-office systems. The analysis result revealed that technological compatibility factors had a significant positive influence on TG implementation $(\beta=.37, \mathrm{t}=4.535, \mathrm{p}<0.001)$. This result is consistent with previous studies (Gil-Garcia, Chengalur-Smith, \& Duchessi, 2007; Gottschalk, 2009a; Lam, 2005a; Landsbergen Jr \& Wolken Jr, 2001; Pardo et al., 2011; Ray, Gulla, Gupta, \& Dash, 2009; H. J. J. Scholl, 2005; Veenstra, 2011) These studies concluded that TG could never be implemented without technological compatibility between government organisations. Technology is an important issue in IOP and implementing TG.

The analysis results revealed that IT standards were highly related to technological compatibility. Therefore, IT standards adoption is very important for IOP between government organisations and the consequent implementation of TG. This result agrees with previous studies (Lam, 2005a; Laskaridis et al., 2007; Pardo et al., 2011; Ray, Gulla, Dash, \& Gupta, 2011). Updating and modifying IT standards is essential. Hence, more attention should be paid by government officials to build, modify and update IT Standards to achieve a high order of IOP among heterogeneous government organisations.

The analysis result revealed that architecture IOP was highly correlated with technological compatibility. Therefore, architecture IOP is a critical factor to build IOP between government organisations. This result is consistent with previous studies (Gottschalk, 2009a; Lam, 2005a; Ray et al., 2011; Weerakkody \& Dhillon, 2008). It is important to have consistent architecture to unify platform differences and facilitate integration between government organisations to provide e-services. Therefore, more effort will be required to overcome this challenge, including defining architecture IOP.

The analysis findings indicated that data requirements were highly correlated with technological compatibility. A fundamental requirement of any EG service is the ability to exchange data seamlessly (Lam, 2005a). This result is consistent with previous studies (Lam, 2005b; Landsbergen Jr \& Wolken Jr, 2001; Ray et al., 2009). However, government organisations always seem hesitant to share data with others; they do not share data due to the possibility of losing power. Kurdi (2013), indicated that data sharing does not exist in many Saudi organisations and new legislation will be required to help organisations benefit from data sharing. There is a need for data classification to define what categories and criteria the organization will use to classify data and specify the roles and responsibilities regarding data ownership. Therefore, more effort is needed by policy makers and EG officials to address this issue. This can be achieved by defining access rights to data, monitoring sensitive information and passing data ownership legislation. This will facilitate the exchange of data and information in an efficient and safe way.

The analysis confirmed that back-office systems were highly correlated with technological compatibility. Integration between organisational back-office systems is the most important factor for IOP and is critical for TG implementation. This result is reasonable due to back-office systems being the 'back bone' of TG implementation between government organisations. The importance of integration between government back-office systems increases in the TG stage and all participants should be integrated seamlessly. This result is consistent with previous studies (Bekkers, 2005; Gottschalk, 2009a; Weerakkody \& Dhillon, 2008). More effort is required from EG officials and policy makers. More specifically, back-office streamlining is required to increase compatibility between back-office systems and achieve TG implementation.

Based on the discussion above, technological compatibility factors positively influenced the IOP required for TG implementation. A higher level of technological compatibility required a more advanced level of IOP and TG. EG officials and policy makers should pay more attention to technological compatibility factors. More technological compatibility between government organisations will ensure a more advanced level of IOP.

\subsection{The Impact of Organisational Compatibility (OC) Factors}

$\mathrm{H} 2$ : organisational compatibility factors positively influence the level of IOP required for TG implementation.

In this study, organisational compatibility factors include IT staff, organisational structure and BPM. The analysis 
results of $\mathrm{H} 2$ showed that $\mathrm{OC}$ factors had a significant impact on the IOP required for TG implementation $(\beta=.33$, $\mathrm{t}=4.110, \mathrm{p}<0.001$ ). This result is consistent with previous studies (Landsbergen Jr \& Wolken Jr, 2001; Ray et al., 2009; H. J. J. Scholl, 2005). Each of these factors is discussed in detail in the next paragraphs.

IT staff was significantly correlated to organisational compatibility. Therefore, IT staff is an important issue for the IOP required to implement TG. This result is consistent with previous studies (Lam, 2005a; Pardo et al., 2011; Weerakkody \& Dhillon, 2008). There is a need for IT training during the implementation of TG projects to help government organisations be aware of and face the challenges that can arise from such projects. Also, qualified IT specialists made a difference between organisations when implementing projects. More attention should be paid by EG officials and policy makers to this issue, to ensure that government organisations have sufficient numbers of IT staff to help with TG implementation. Government organisations must provide training programs for their employees, or employ skilled employees (perhaps outsourced) to fill this gap.

Analysis result showed that organisational structure was highly correlated with organisational compatibility and consequently to IOP between government organisations. This result aligns with previous studies in the literature (Lam, 2005a; Pardo et al., 2011; Weerakkody \& Dhillon, 2008). The reason for this is that organisational structure can facilitate the organisation's business goals by arranging thousands of employees and managers, who are often split between numerous locations and functions, in an effective and cost-efficient fashion (Altameem, Zairi, \& Alshawi, 2006). A suitable structure will help them to integrate easily. However, government organisations in Saudi Arabia typically have a hierarchical structure, and this will hinder IOP. This result is consistent with Al-Fakhri, Cropf, Higgs, and Kelly (2009) study, which indicated that organisation structures not being appropriate to EG implementation in Saudi Arabia. Therefore, the council of ministers has called on government organisations to establish their own internal EG committees (Yesser, 2015a). This committee is required to report to a senior official It includes members from different backgrounds such as IT, finance and management. More attention should be paid to adopting a more flexible and convenient structure to ensure the success of TG implementation projects.

The analysis result showed that business process management was highly correlated to organisational compatibility. Therefore, it is a very important factor in facilitating IOP between government organisations and the consequent TG implementation. This result aligns with previous studies' findings (Hellman, 2010; Laskaridis et al., 2007). However, some organisations had not started managing their business processes yet. Some did not have the knowledge or expertise to manage their business processes. Some had not documented their business processes. Therefore, policy makers and EG officials should make more effort and escalate government organisation's streamlining and unifying of business processes by establishing a clear strategic for planning, controlling and monitoring business process management. They should also ensure that all participants agree on the final output or result.

The analysis results reveal that organisational compatibility factors positively influence the IOP required for TG implementation. The higher the level of organisational compatibility, the more advanced the level of IOP and TG. EG officials should pay more attention to organisational compatibility factors. The more compatibility between government organisations, the more advanced the level of EG IOP.

\subsection{The Impact of Governance Readiness (GR) Factors}

H3: governance readiness factors positively influence the level of IOP required for TG implementation.

Governance readiness factors for this study include funding, strategies and regulations, leadership, and stakeholders. The analysis of $\mathrm{H} 3$ revealed that all governance readiness factors for this study (strategies \& regulations, leadership, and stakeholders) have a significant positive influence on TG implementation. The funding factor is not included, as it does not influence TG implementation in the Saudi Arabian context. The analysis showed a significant impact of the governance readiness factor on the IOP required for TG implementation ( $\beta$ $=.18, \mathrm{t}=2.425, \mathrm{p}<0.05)$. This result is consistent with previous studies (Lam, 2005a; Landsbergen Jr \& Wolken Jr, 2001; Pardo et al., 2011; Ray et al., 2009). Each of these factors is discussed in detail in the next paragraphs.

Funding is the most important factor for any kind of EG project. Many EG projects fail or are cancelled for this reason. However, the analysis findings show that the funding factor has only a slight relationship to TG implementation. Funding is not an obstacle to TG in Saudi Arabia. The analysis result reveals that funding alone is not an obstacle. This result is inconsistent with previous studies (Eyob, 2004; Gottipati, 2002), which indicate that funding is the main obstacle to EG transformation. This result is not surprising due the level of support from King Abdullah for EG transformation. The Saudi government has already invested billions of dollars in developing EG services (MCIT, 2014; Yesser, 2015a). The result indicated that funds monitoring and management is another concern in the completion of successful EG projects. This is consistent with studies that suggest funds alone have a low impact on EG implementation projects (Al-Fakhri et al., 2009; Altameem et al., 2006). More effort should 
be considered to create plans and strategies to speed up the financial support of EG projects and to monitor fund allocation. Providing financial support on time could lead to faster implementation and increase the number of EG initiatives completed on time (Al-Rashidi, 2013).

The analysis finding indicates that leadership is highly correlated to governance readiness. Therefore, leadership is an important factor for creating the IOP required to implement TG. This result agrees with previous studies in the literature (Lam, 2005a; Pardo et al., 2011; Tripathi, Gupta, \& Bhattacharya, 2013). Leadership is critical to the success of TG implementation projects. However, they did note the support from King Abdullah. Government organisations need strong leadership to speed up and follow up on these projects to completion. In addition, knowledgeable leaders who understand the technology, legislation and policy goals play a vital role in the outcome of any EG project. A leader will push their organisation to success. Hence, leadership is a crucial factor in TG implementation.

The analysis result indicated that strategies and regulations were highly correlated with governance readiness. The results also pinpoint and identify strategies and regulations as important factors for creating the IOP required for TG implementation. This is consistent with previous studies in the literature (Hellman, 2010; Ray et al., 2011). However, some organisations did not have clear strategies, plans or regulations for EG transformation. Additionally, some organisations did not have a structured approach to EG strategy formulation and development. Moreover, some organisations involved only managers in creating and designing their strategies. Organisations may only have strategies on paper that are not implemented. There are gaps between EG strategies and real life implementation (Alshehri \& Drew, 2010). Al-Solbi and Al-Harbi (2008) found a lack of shared strategies and regulations for EG in Saudi Arabia. Strategy and regulations are very important issues; they should cover every aspect of TG implementation projects. Although, EG officials and policy makers have developed many strategies and regulations to support EG implementation, more attention should be paid to define shared goals and vision between government organisations. This will facilitate the goal of TG implementation. According to Kurdi (2013), the Saudi government has issued several strategies and regulations; however, most have not been published (as required for EG adoption). The strategies and regulations are insufficient. Therefore, EG officials and policy makers need to learn from experts in other countries regarding how to design an effective strategy. They also need to compare the current regulations and change them if required, to facilitate TG implementation. They need to involve and coordinate all participants in creating and designing strategies. This will help to overcome the lack of commitment to the strategy. Commitment to a chosen strategy is a greater determinant of that strategy's success than the particular strategy chosen (Lam, 2005a). If each of these steps is considered, strategies and regulations can successfully ensure the sustainability of IOP required for TG implementation.

The analysis results found that stakeholders were highly correlated with governance readiness. Therefore, leadership is an important factor for creating the IOP required to implement TG. This result is consistent with (AlSebie \& Irani, 2005; M. Kamal, Weerakkody, \& Irani, 2011). 'Stakeholders' refers to any group or individual who can affect, or is affected by, achieving the organisation's objectives (Freeman, 2010). Stakeholder recognition in EG has a significant role to play in ensuring the long-term success of EG enterprises (Rowley, 2011). Few studies have examined stakeholder challenges in implementation and integration projects between government organisations (M. Kamal et al., 2011), and EG officials and managers have already realised the importance of stakeholders to achieving successful TG implementation projects in Saudi Arabia. The analysis stressed the importance of involvement and collaboration between all stakeholders, especially in EG projects that require integration, such as TG implementation projects. However, there are difficulties remain regarding cooperation between government organisations in Saudi Arabia. Government organisations in Saudi Arabia are organised in a hierarchical way, which means the top managers of government organisations decide on the policy to be implemented by the remaining stakeholders. The top managers steer stakeholders through detailed regulations and control the implementation of regulations and procedures. This will not help stakeholders, such as qualified IT staff, to participate in the decision-making process. Hence, efforts should be made by policy makers and EG officials to address this problem, encouraging and managing government organisation participation, ensuring all stakeholders are involved in the implementation of TG. Officials should listen to all stakeholders to obtain their perspectives.

The analysis results reveal that governance readiness factors positively influence the IOP required for TG implementation. Governance readiness factors are required to give direction to development, coordinate efforts and decision-making processes (Janssen, Charalabibis, Kuk, \& Cresswell, 2011). The higher the level of governance readiness, the more advanced the levels of IOP and TG. It is clear that EG officials and policy makers should pay more attention to their governance readiness. They need to cooperate to ensure that their strategies, regulations, policies and governance frameworks are compatible. They need to review frameworks and evaluate 
them at least every two years, updating as necessary. Governance must be agreed between collaborating organisations. The more compatible the governance between government organisations, the more advanced the level of EG IOP.

\subsection{The Impact of Citizen Centricity (CC) Factors}

H4: citizen centricity positively influences the level of IOP required for TG implementation.

The analysis of $\mathrm{H} 4$ shows that citizen centricity has a negative influence on the IOP required for TG implementation $(\beta=-.13, t=-1.990, p<0.05)$. This is contrary to the research literature's expectation as path's direction is proposed as positive (Gouscos, Kalikakis, Legal, \& Papadopoulou, 2007; Irani, 2007; Weerakkody \& Dhillon, 2008). This results align with Reddick (2005), who concluded that citizen centricity has not been explored yet. The survey participants were not able to recognise the relationship between citizen centricity and TG.

The analysis has revealed many possible reasons for the statistically negative relationship between citizen centricity and TG implementation. First of all, many organisations still do not know about the concept of citizen centricity. This confirms a previous finding by Al-Sobhi, Weerakkody, and Kamal (2010); Alateyah, Crowder, and Wills (2013) who indicate that little attention has been paid to citizen centric perceptions and usability, accessibility and the availability of EG services in Saudi Arabia. Alshehri and Drew (2010) note that 55\% of participants in their study were not satisfied with current EG services. This is also consistent with Alzaheani and Goodwin (2012), who argue that EG services in Saudi Arabia are still at an early stage in terms of citizen centricity. This aligns with Al-Nuaim (2011) who has reported that Saudi ministry websites are still in the early stages regarding citizen centricity. Also, there is no measurement of citizen satisfaction exists with Saudi EG. This is consistent with the UN report findings of their EG survey. The UN report noted the e-participation index (EPI) indicates that Saudi Arabia achieved $85.19 \%$ in Stage 1,27.27\% in Stage 2, and $11.11 \%$ in Stage 3. This means there is a gap in the citizen-centric focus (UN, 2014). In addition, government organisations in Saudi Arabia do not implement their services according to citizens' needs. This is consistent with (Abanumy, Al-Badi, \& Mayhew, 2005; Chatfield \& AlAnazi, 2015). These researchers suggest that government organisations in Saudi Arabia do not meet their citizen's expectations.

Little interaction exists between citizens and government organisations on social media platforms. According to Alfirm (2014), although social media increases levels of satisfaction and enhances the chances of EG service success by giving the EG user the ability to communicate and interact with government organisations easily, the majority of Saudi government organisations do not use social media to deliver services. Therefore, it is important to use social media effectively. Government organisations should increase their investment in social media. This is consistent with a previous study (Alateyah et al., 2013). These above reasons may be evidence for why citizen centricity had a negative impact on the IOP required for Saudi TG implementation.

Based on the discussion above, to achieve the TG stage, EG services should be citizen centric. Users need to access one single point to obtain services. This requires government organisations to be interoperated seamlessly to provide these e-services. Users should also be able to access EG services through computer-mediated tools such as social media. Therefore, policy makers and EG officials should pay more attention to citizens' needs and satisfaction, and these should be measured regularly. They should also pay attention to the importance of implementing social media to strengthen interaction with citizens. Designers can develop services that meet the goals of the government and the needs of the citizens, but if the target users do not consider them accessible and usable, they may not adopt those services. In turn, the services will not realise their full potential (Marc \& Grace A., 2012).

\subsection{The Impact of EG Program (Yesser) Factors}

H5: the EG program (Yesser) positively influences the level of IOP required for TG implementation.

The analysis result reveals that Yesser has an insignificant influence on TG implementation of TG $(\beta=.12, \mathrm{t}=$ 1.705). This result is inconsistent with previous studies (Irani, 2007; Weerakkody \& Dhillon, 2008).

The possible reason for this is that most of survey participants had been involved in EG development government organisations and may have had negative experiences with the EG program (Yesser). They did not think Yesser was important. This is consistent with Almahroqi (2012) study, where he indicates that there is lack of knowledge about Yesser. Yesser was designed to enhance government organisation productivity and should help in terms of methodologies, data, standards and knowledge to enable easy integration successful TG implementation. Despite this, many were not satisfied with Yesser's outcomes. They noted that Yesser and its integrity with other EG projects was lacking; they felt that Yesser was responsible for delays in the integration between government organisations. This is consistent with Alghamdi, Goodwin, and Rampersad (2013) findings. They stated a delay 
existed regarding connections with Yesser and this will lead to a decrease in EG readiness levels. An EG team member also noted that Yesser did not have enough power to force government organisations to implement the initiatives and products in their organisations. Therefore, many organisations failed to follow Yesser's initiatives. All of these above reasons may be evidence that Yesser has had no significant impact on IOP required for TG implementation. More power should be invested in Yesser, enabling initiatives to be followed up. The EG program (Yesser) should encourage more effort to help government organisations benefit from Yesser's initiatives. More coordination is needed to facilitate the integration between government organisations. More power is required from an authorised government agency to follow up government organisations to implement Yesses's initiatives and regulations. More effort is also required from EG officials and policy makers to obtain advantage from Yesser's initiatives.

\subsection{Other Inter-Relationships}

This section discusses the other relationships, including those between citizen centricity and the EG program (Yesser), the EG program (Yesser) and technological compatibility, the EG program (Yesser) and organisational compatibility and the EG program (Yesser) and governance readiness.

\subsubsection{The Impact of CC on the EG Program (Yesser)}

H6: citizen centricity positively influences the EG program (Yesser).

The analysis of $\mathrm{H} 6$ reveals that citizen centricity had a positive influence on the EG program (Yesser) $(\beta=.23, t=$ $3.238, \mathrm{p}<0.01$ ). This is consistent with one of the objectives for creating Yesser, which was to provide better, more convenient and more seamlessly integrated EG services for citizens (Yesser, 2015). This was confirmed by the EG strategy in Saudi Arabia. The rate of citizen-centric focus promoted an EG program in Saudi Arabia that encouraged citizen-centric integrated interoperable EG services, starting with the Saudi EG national portal as a central hub for all government services. The Saudi EG national portal 'Saudi' was launched in 2006. The aim of this was to improve government transparency in public services radically and to empower citizens by providing enhanced accessibility to existing EG services through the internet (Yesser, 2015a). This result is consistent with previous studies (Chatfield \& AlAnazi, 2015; Ebrahim \& Irani, 2005; Layne \& Lee, 2001). It is essential to take a citizen-centric approach as a guideline to implementing EG services; that is, to understand the needs and requirements of citizens when building up and processing the technology.

\subsubsection{The Impact of the EG Program (Yesser) on TC, OC and GR}

H7: the EG program (Yesser) has a positive impact on technological compatibility.

The analysis of $\mathrm{H} 7$ reveals that the EG program (Yesser) has a positive influence on technological compatibility $(\beta=.23, t=3.238, p<0.01)$. This result is consistent with previous studies (Chatfield \& AlAnazi, 2015). Yesser has built reliable infrastructure that facilitated EG implementation and enabled data exchange between government organisations. More power should be invested in Yesser to enable follow up regarding initiative implementation. The EG program (Yesser) should also enable government organisations to benefit from Yesser initiatives.

H8: the EG program (Yesser) has a positive impact on organisational readiness.

The analysis of $\mathrm{H} 8$ reveals that the EG program (Yesser) had an insignificant influence on organisational readiness $(\beta=.15, \mathrm{t}=1.872)$. This result is consistent with previous studies (Chatfield \& AlAnazi, 2015). The reason for this could be that Yesser does not address organisational issues such as BPM and organisational structure properly. Yeseer is concerned with technical issues, but there is no tangible effort regarding organisational issues. More effort related to organisational issues is required to help government organisations become compatible organisationally to achieve the IOP level required for TG implementation

H9: the EG program (Yesser) positively influences governance readiness.

The analysis of $\mathrm{H} 9$ reveals that the EG program (Yesser) had a positive influence on governance readiness $(\beta=.26$, $\mathrm{t}=3.017, \mathrm{p}<0.01)$. Yesser has built EG strategy, plan or regulations to move towards and implement EG. More effort is needed from Yesser to help government organisations achieve governance readiness. This result is consistent with Chatfield and AlAnazi (2015) study. This study highlighted that the EG program in Saudi Arabia used a national EG strategy for improving governance at the national level, to motivate and facilitate EG implementation across all Saudi government agencies, and to provide better, more convenient and more seamlessly integrated EG services for citizens and business customers (Yesser, 2015a). 


\section{Conclusion, Limitations and Future Recommendations}

The main aim of this paper is to develop an integrated model that increase the IOP level required for TG implementation. This model offers a contribution that illustrates the factors affecting the IOP level required for TG implementation from four key areas: organisational, technological, social and political. The model uses institutional theory as a lens. It focuses only on the factors that affect IOP between government organisations; on internal categories and in particular, G2G factors, which represent the relationship between governments collaborating to achieve TG. This includes central G2G strategies that represent the relationship between a central coordinating or consultative body.

These factors are technological compatibility, organisational compatibility, governance readiness, citizen centricity and the e-Government program (Yesser). This paper found that technological compatibility, organizational compatibility, and governance readiness have a positive impact on the interoperability required for the implementation of t-Government in this particular context. Unexpectedly, it indicates that citizen centricity has negative impact on the interoperability required for the implementation of t-Government. It also shows that there is a direct and positive impact from e-Government program (Yesser) to technological compatibility and governance readiness. Moreover, it shows that there is a direct and positive impact from citizen centricity to e-Government program (Yesser). Unexpectedly, the results indicate that e-Government program (Yesser) has no impact on the interoperability required for the implementation of t-Government. It also indicats that the e-Government program (Yesser) doesn't affect organizational compatibility.

This paper suggests a generic, usable and comprehensive picture of the key factors influencing t-Government implementation. This will help e-Government officials and policy makers to become more proactive, creating a holistic view to understand the factors that hinder interoperability between government organisations and tGovernment implementation in Saudi Arabia. It helps them identify the gaps they need to fill, determine the weaknesses they need to improve and define their exact target in implementing t-Government. Using institutional theory also offers practitioners conceptual tools and techniques for understanding complex change-management scenarios (Shoib, Nandhakumar, \& Currie, 2009). This will enable effective planning for organisational change. It also can help government organisations to develop roadmaps and strategies by warning them of the key factors that stimulate or impede t-Government implementation.

This study has two limitations. First, the sample size is not large enough to generalize results to the entire country, as Saudi Arabia is a large country and larger sample size would be preferable, augmented by more samples from government organisations in Saudi Arabia. This would strengthen the results. Another limitation is related to geographical location. Although a revised model has been presented, based on validation through data collection and analysis in Saudi Arabia, it might be difficult to generalise to other countries (such as Gulf or Arab countries) due to different environments and contexts until it is tested and validated in each country. Therefore, further study in different countries would most likely reinforce and validate this model.

\section{References}

Abanumy, A., Al-Badi, A., \& Mayhew, P. (2005). e-Government Website accessibility: in-depth evaluation of Saudi Arabia and Oman. The Electronic Journal of e-Government, 3(3), 99-106.

Abramowicz, W., Bassara, A., Wisniewski, M., \& Zebrowski, P. (2008). Interoperability Governance for eGovernment. In R. Kaschek, C. Kop, C. Steinberger, \& G. Fliedl (Eds.), Information Systems and e-Business Technologies (Vol. 5, pp. 14-24): Springer Berlin Heidelberg.

Al-Fakhri, M. O., Cropf, R. A., Higgs, G., \& Kelly, P. (2009). E-government in Saudi Arabia: Between promise and reality. Social and Organizational Developments through Emerging E-Government Applications: New Principles and Concepts: New Principles and Concepts, 166.

Al-Khouri, A., \& Bal, J. (2007). Electronic government in the GCC countries. International Journal of Social Sciences, 1(2), 83-98.

Al-Khouri, A. M. (2011). An innovative approach for e-government transformation. arXiv preprint arXiv:1105.6358.

Al-Nuaim, H. (2011). An evaluation framework for Saudi e-government. Journal of e-Government Studies and Best Practices, 2011, 1-12.

Al-Rashidi, H. (2013). The role of internal stakeholders and influencing factors during the phases of e-government initiative implementation. Brunel University, School of Information Systems, Computing and Mathematics. 
Al-Sebie, M., \& Irani, Z. (2005). Technical and organisational challenges facing transactional e-government systems: an empirical study. Electronic Government, an International Journal, 2(3), 247-276.

Al-Sobhi, F., Weerakkody, V., \& Kamal, M. M. (2010). An exploratory study on the role of intermediaries in delivering public services in Madinah City: Case of Saudi Arabia. Transforming Government: People, Process and Policy, 4(1), 14-36.

Alateyah, S. A., Crowder, R. M., \& Wills, G. B. (2013). An integrated model for influencing Saudi Arabian citizens to adopt E-government services. Paper presented at the Proceedings of the International Conference on Cloud Computing and eGovernance.

Alfirm, K. (2014). The low use of Social media in the public sectors.

Alghamdi, I. A., Goodwin, R., \& Rampersad, G. (2013). Evaluation of Organizational E-Government Readiness in the Public Sector. International Journal of E-Services and Mobile Applications (IJESMA), 5(2), 1-21.

Almahroqi, O. T. (2012). Factors Influencing Citizen's Adoption Of E-Government Services In Saudi Arabia. RMIT University.

Alshehri, M., \& Drew, S. (2010). Challenges of e-government services adoption in Saudi Arabia from an e-ready citizen perspective. Education, 29(5.1).

Alshetewi, S., Goodwin, R., Karim, F., \& de Vries, D. (2015). A Structural Equation Model (SEM) of Governing Factors Influencing the Implementation of T-Government (IJACSA) International Journal of Advanced Computer Science and Applications, 6(11), 119-125.

Altameem, T., Zairi, M., \& Alshawi, S. (2006). Critical success factors of e-government: A proposed model for egovernment implementation. Paper presented at the Innovations in Information Technology, 2006.

Alzaheani, M., \& Goodwin, R. (2012). Towards a UTAUT-based Model for the Study of E-Government Citizen Acceptance in Saudi Arabia. World Academy of Science, Engineering and Technology, Vol:6 (2012-04-23).

Archmann, S. (2007). eGovernment Services: Interoperability Success Factors, Inclusions and Accessibility. Fostering Public Sector Performance in Europe, 128.

Bekkers, V. (2005). The governance of back office integration in e-government: Some dutch experiences Electronic Government (pp. 12-25): Springer.

Budhiraja, R. (2012). Challenges and Role of Standards in Building Interoperable e-Governance Solutions. CiteSeer.

Byrne, B. M. (2013). Structural equation modeling with AMOS: Basic concepts, applications, and programming: Routledge.

Chandler, S., \& Emanuels, S. (2002). Transformation not automation. Paper presented at the Proceedings of 2nd European Conference on E-government.

Chatfield, A. T., \& AlAnazi, J. (2015). Collaborative Governance Matters to E-Government Interoperability: An Analysis of Citizen-Centric Integrated Interoperable E-Government Implementation in Saudi Arabia. International Journal of Public Administration in the Digital Age (IJPADA), 2(3), 24-44.

Davenport, T. H. (2013). Process innovation: reengineering work through information technology: Harvard Business Press.

Davidson, W. H. (1993). Beyond re-engineering: the three phases of business transformation. IBM systems journal, 32(1), 485-499.

Decoster, S. A., \& Zwicker, R. (2009). Barriers for transformation: Impediments for transforming the public sector through e-government.

Dos Santos, E. M., \& Reinhard, N. (2011). Electronic government interoperability: Identifying the barriers for frameworks adoption. Social Science Computer Review, 0894439310392196.

Ebrahim, Z., \& Irani, Z. (2005). E-government adoption: architecture and barriers. Business Process Management Journal, 11(5), 589-611.

Elliman, T., Sarikas, O. D., \& Weerakkody, V. (2007). Realising integrated e-government services: a UK local government perspective. Transforming Government: People, Process and Policy, 1(2), 153-173.

Elnaghi, M., AlShawi, S., Weerakkody, V., \& Aziz, W. (2009). Instigating Transformational Government at a Municipality Level: A Case Study. Handbook of Research on ICT-Enabled Transformational Government: A 
Global Perspective, 72.

Eyob, E. (2004). E-government: breaking the frontiers of inefficiencies in the public sector. Electronic Government, an International Journal, 1(1), 107-114.

Ezz, I. E., \& Papazafeiropoulou, A. (2006). Inter-organisational collaboration towards process integration in the public sector. E-government collaboration in Egypt. Paper presented at the System Sciences, 2006. HICSS'06. Proceedings of the 39th Annual Hawaii International Conference on.

Feuerlicht, J., \& Cunek, D. (2011). Towards e-Government Interoperability Framework. Paper presented at the DATESO.

Freeman, R. E. (2010). Strategic management: A stakeholder approach: Cambridge University Press.

Garlan, D., Allen, R., \& Ockerbloom, J. (1995). Architectural mismatch or why it's hard to build systems out of existing parts. Paper presented at the Software Engineering, 1995. ICSE 1995. 17th International Conference on.

Gil-Garcia, J. R., Chengalur-Smith, I., \& Duchessi, P. (2007). Collaborative e-Government: impediments and benefits of information-sharing projects in the public sector. European Journal of Information Systems, 16(2), 121-133.

Gottipati, M. (2002). Managing e-government portals, Eighth GCC e-government. Paper presented at the Internet $\&$ telecommunications forum, May 28.

Gottschalk, P. (2009a). E-Government Interoperability and Information Resource Integration: Frameworks for Aligned Development: Frameworks for Aligned Development: IGI Global.

Gottschalk, P. (2009b). Maturity levels for interoperability in digital government. Government Information Quarterly, 26(1), 75-81.

Gouscos, D., Kalikakis, M., Legal, M., \& Papadopoulou, S. (2007). A general model of performance and quality for one-stop e-government service offerings. Government Information Quarterly, 24(4), 860-885.

Grover, V., Jeong, S. R., Kettinger, W. J., \& Teng, J. T. (1995). The implementation of business process reengineering. Journal of Management Information Systems, 109-144.

Hair, J. F. (2010). Multivariate data analysis.

Heeks, R. (1999). Reinventing government in the information age: International practice in IT-enabled public sector reform (Vol. 1): Psychology Press.

Heeks, R., \& Stanforth, C. (2007). Understanding e-Government project trajectories from an actor-network perspective. European Journal of Information Systems, 16(2), 165-177.

Hellman, R. (2010). Organisational Barriers to Interoperability. Paper presented at the eChallenges e-2010, Poland.

Herbert, K., \& Ralf, C. (2009). Three Dimensions of Organizational Interoperability: Insights from Recent Studies for Improving Interoperability Frameworks. European Journal of ePractice 3.

Hoffman, Z. (1997). Business process re-engineering: a new strategic paradigm shift in change management. Paper presented at the Bay Zoltan Foundation for Applied Research Institute for Logistics and Production Engineering.

Hossan, C. G., Habib, M. W., \& Kushchu, I. (2006). Success and Failure Factors for e-Government projects implementation in developing countries: A study on the perception of government officials of Bangladesh. Paper presented at the Poster session presented at the proceedings of 2th European Conference on Mobile Government. Retrieved March.

Hreño, J., Bednár, P., Furdík, K., \& Sabol, T. (2011). Integration of government services using semantic technologies. Journal of theoretical and applied electronic commerce research, 6(1), 143-154.

Hu, P. J.-H., Cui, D., \& Sherwood, A. C. (2006). Examining cross-agency collaborations in e-government initiatives. Paper presented at the System Sciences, 2006. HICSS'06. Proceedings of the 39th Annual Hawaii International Conference on.

Huang, Z., \& Bwoma, P. O. (2003). An overview of critical issues of e-government. Issues of Information Systems, $4(1), 164-170$.

Irani, Z. (2007). T-government for benefit realisation. Paper presented at the Proceedings of the European and 
Mediterranean Conference on Information Systems.

Janssen, M., Charalabibis, Y., Kuk, G., \& Cresswell, T. (2011). Guest Editors' Introduction: E-government Interoperability, Infrastructure and Architecture: State-of-the-art and Challenges. Journal of theoretical and applied electronic commerce research, 6(1), I-VIII.

Janssen, M., \& Cresswell, A. M. (2005). An enterprise application integration methodology for e-government. Journal of Enterprise Information Management, 18(5), 531-547.

Janssen, M., \& Scholl, H. J. J. (2007). Interoperability for electronic governance. Paper presented at the Proceedings of the 1st international conference on Theory and practice of electronic governance.

Kamal, M., \& Alsudairi, M. (2009). Investigating the importance of factors influencing integration technologies adoption in local government authorities. Transforming Government: People, Process and Policy, 3(3), 302331.

Kamal, M., Weerakkody, V., \& Irani, Z. (2011). Analyzing the role of stakeholders in the adoption of technology integration solutions in UK local government: An exploratory study. Government Information Quarterly, 28(2), 200-210.

Kamal, M. M., Themistocleous, M., \& Morabito, V. (2009). Justifying the decisions for EAI adoption in LGAs: a validated proposition of factors, adoption lifecycle phases, mapping and prioritisation of factors. Paper presented at the System Sciences, 2009. HICSS'09. 42nd Hawaii International Conference on.

Klievink, B., \& Janssen, M. (2010). Coordinating e-government service delivery. Paper presented at the Proceedings of the 11th Annual International Digital Government Research Conference on Public Administration Online: Challenges and Opportunities.

Klischewski, R. (2004). Information integration or process integration? How to achieve interoperability in administration Electronic Government (pp. 57-65): Springer.

Klischewski, R. (2011). Architectures for Tinkering?: Contextual Strategies towards Interoperability in Egovernment. Journal of theoretical and applied electronic commerce research, 6(1), 26-42.

Klischewski, R., \& Scholl, H. J. (2006). Information quality as a common ground for key players in e-government integration and interoperability. Paper presented at the System Sciences, 2006. HICSS'06. Proceedings of the 39th Annual Hawaii International Conference on.

Kubicek, H., Cimander, R., \& Scholl, H. J. (2011). Organizational Interoperability in E-Government. SpringerVerlag Berlin Heidelberg: Springer Berlin Heidelberg.

Kurdi, R. F. (2013). An investigation of readiness assessments for e-government information system and cloud computing using Saudi Arabia as a case study. Liverpool John Moores University.

Lam, W. (2005a). Barriers to e-government integration. Journal of Enterprise Information Management, 18(5), 511-530.

Lam, W. (2005b). Investigating success factors in enterprise application integration: a case-driven analysis. Eur. J. Inf. Syst., 14(2), 175-187. https://doi.org/10.1057/palgrave.ejis.3000530

Lampathaki, F., Kroustalias, N., Koussouris, S., Charalabidis, Y., \& Psarras, J. (2010). Implementing interoperability infrastructures: Issues and challenges from the citizens' base registry in Greece. Paper presented at the System Sciences (HICSS), 2010 43rd Hawaii International Conference on.

Landsbergen Jr, D., \& Wolken Jr, G. (2001). Realizing the promise: Government information systems and the fourth generation of information technology. Public administration review, 206-220.

Laskaridis, G., Markellos, K., Markellou, P., Panayiotaki, A., Sakkopoulos, E., \& Tsakalidis, A. (2007). Egovernment and Interoperability Issues. International Journal of Computer Science and Network Security, 7(9), 28-38.

Layne, K., \& Lee, J. (2001). Developing fully functional E-government: A four stage model. Government Information Quarterly, 18(2), 122-136.

Lee, J. (2010). 10 year retrospect on stage models of e-Government: A qualitative meta-synthesis. Government Information Quarterly, 27(3), 220-230. https://doi.org/10.1016/j.giq.2009.12.009

Lindquist, E. A. (2013). Putting Citizens First: Engagement in Policy and Service Delivery for the 21st Century: ANU E Press. 
Luk, S. C. Y. (2009). The impact of leadership and stakeholders on the success/failure of e-government service: Using the case study of e-stamping service in Hong Kong. Government Information Quarterly, 26(4), 594604.

Lynn, C. J. H. L. E., Heinrich, C. J., \& Lynn Jr, L. E. (2000). Governance and performance: New perspectives: Georgetown University Press.

Malinauskienè, E. (2013). Conceptual framework for context-based e-government interoperability development. Social Technologies, (01), 68-84.

Marc, N., \& Grace A. L. (2012). Interoperability in the e-Government Context. Retrieved from Carnegie Mellon University:

MCIT. (2014). The Development Stages of ICT in Saudi Arabia 2012. Retrieved from MCIT: http://www.mcit.gov.sa/En/AboutMcit/SectorDevelopment/Pages/DevelopmentStages.aspx

Michael Hammer, \& Champy, J. (1994). Reviewed Work: Reengineering the Corporation: A Manifesto for Business Revolution The Academy of Management Review, 19(3), 595-600. https://doi.org/ 10.2307/258943

Moon, M. J. (2002). The evolution of e-government among municipalities: rhetoric or reality? Public administration review, 62(4), 424-433.

Müller, H. A., Tilley, S. R., \& Wong, K. (1993). Understanding software systems using reverse engineering technology perspectives from the rigi project. Paper presented at the Proceedings of the 1993 conference of the Centre for Advanced Studies on Collaborative research: software engineering-Volume 1.

Pardo, T. A., \& Burke, G. B. (2008a). Government worth having: A briefing on interoperability for government leaders. Center for Technology in Government, University at Albany, SUNY Oct.

Pardo, T. A., \& Burke, G. B. (2008b). Improving Government Interoperability: A capability framework for government managers. Center for Technology in Government, University of Albany.

Pardo, T. A., Nam, T., \& Burke, G. B. (2011). E-government interoperability: Interaction of policy, management, and technology dimensions. Social Science Computer Review, 0894439310392184.

PWC. (2012). Transforming the citizen experience One Stop Shop for public services. Retrieved from

Ray, D., Gulla, U., Dash, S. S., \& Gupta, M. (2011). A critical survey of selected government interoperability frameworks. Transforming Government: People, Process and Policy, 5(2), 114-142.

Ray, D., Gulla, U., Gupta, M., \& Dash, S. S. (2009). Interoperability and constituents of interoperable systems in public sector. Handbook of Research on ICT-enabled Transformational Government: A Global Perspective, IGI Global, Hershey, PA, 175-195.

Reddick, C. G. (2005). Citizen interaction with e-government: From the streets to servers? Government Information Quarterly, 22(1), 38-57. Retrieved from http://ac.els-cdn.com/S0740624X0400067X/1-s2.0S0740624X0400067X-main.pdf?.tid=bb4c613c-cf8a-11e5-83e700000aacb360\&acdnat=1455063226_d5b3cf7d03e6ff936dc0e3a26b7f09da

Rosacker, K. M., \& Olson, D. L. (2008). Public sector information system critical success factors. Transforming Government: People, Process and Policy, 2(1), 60-70.

Rowley, J. (2011). e-Government stakeholders-Who are they and what do they want? International Journal of Information Management, 31(1), 53-62.

Sarantis, D., Charalabidis, Y., \& Psarras, J. (2008). Towards standardising interoperability levels for information systems of public administrations. The Electronic Journal for E-commerce Tools \& Applications (eJETA) Special Issue on Interoperability for Enterprises and Administrations Worldwide, 2.

Scholl, H. J. (2004). Involving salient stakeholders Beyond the technocratic view on change. Action Research, 2(3), 277-304.

Scholl, H. J., \& Klischewski, R. (2007). E-government integration and interoperability: framing the research agenda. International Journal of Public Administration, 30(8-9), 889-920.

Scholl, H. J. J. (2005). Interoperability in e-Government: More than just smart middleware. Paper presented at the System Sciences, 2005. HICSS'05. Proceedings of the 38th Annual Hawaii International Conference on.

Shareef, M. A., Kumar, V., Kumar, U., \& Dwivedi, Y. K. (2011). e-Government Adoption Model (GAM): Differing service maturity levels. Government Information Quarterly, 28(1), 17-35. 
Skiftenes, L. (2006). The state of G2G development: Maturity levels and current challenges. AMCIS 2006 Proceedings, 294.

Soares, D., \& Amaral, L. (2011). Information systems interoperability in public administration: identifying the major acting forces through a Delphi study. Journal of theoretical and applied electronic commerce research, 6(1), 61-94.

Soliman, K. S., Affisco, J. F., Affisco, J. F., \& Soliman, K. S. (2006). E-government: a strategic operations management framework for service delivery. Business Process Management Journal, 12(1), 13-21.

Somers, T. M., \& Nelson, K. (2001). The impact of critical success factors across the stages of enterprise resource planning implementations. Paper presented at the System Sciences, 2001. Proceedings of the 34th Annual Hawaii International Conference on.

Su, S. Y., Xiao, X., DePree, J., Beck, H. W., Thomas, C., Coggeshall, A., \& Bostock, R. (2011). Interoperation of organizational data, rules, processes and services for achieving inter-organizational coordination and collaboration. Paper presented at the System Sciences (HICSS), 2011 44th Hawaii International Conference on.

Tambouris, E., \& Tarabanis, K. A. (2005). e-Government and Interoperability. Paper presented at the ECEG.

Tat-Kei Ho, A. (2002). Reinventing local governments and the e-government initiative. Public administration review, 62(4), 434-444.

Themistocleous, M., Irani, Z., \& Love, P. E. (2005). Developing e-government integrated infrastructures: a case study. Paper presented at the System Sciences, 2005. HICSS'05. Proceedings of the 38th Annual Hawaii International Conference on.

Tripathi, R., Gupta, M., \& Bhattacharya, J. (2012). Identifying factors of integration for an interoperable government portal: a study in Indian context. E-Government Services Design, Adoption, and Evaluation, 67.

Tripathi, R., Gupta, M., \& Bhattacharya, J. (2013). Effect of organizational factors on interoperability adoption for Indian portals. Transforming Government: People, Process and Policy, 7(3), 285-308.

UnitedNations. (2012). E-Government Survey: E-Government for the People. Retrieved from UNPAN: http://www.unpan.org/egovkb/global_reports/08report.htm

UnitedNations. (2014). E-Government Survey: E-Government for the Future We Want. Retrieved from UNPAN: http://www.unpan.org/egovkb/global_reports/08report.htm

Valdés, G., Solar, M., Astudillo, H., Iribarren, M., Concha, G., \& Visconti, M. (2011). Conception, development and implementation of an e-Government maturity model in public agencies. Government Information Quarterly, 28(2), 176-187.

Veenstra, V. (2011). Barriers and impediments to transformational government: insights from literature and practice. Electronic Government.

Weerakkody, V. (2008). Moving from E-Government to T-Government: A Study of Process Reengineering Challenges in a UK Local Authority Context. International Journal of Electronic Government Research,.

Weerakkody, V., \& Dhillon, G. (2008). Moving from e-government to t-government: A study of process reengineering challenges in a UK local authority context. International Journal of Electronic Government Research, 4(4), 1-16.

Yesser. (2006). The e-Government First Action Plan. Retrieved from http://www.yesser.gov.sa/en/MechanismsandRegulations/Documents/National_E-

Gov_Action_Plan_\%28F\%29.pdf

Yesser. (2012). The e-Government Second Action Plan. Retrieved from http://www.yesser.gov.sa/en/MechanismsandRegulations/strategy/Documents/the_2nd_egovernment_action _plan_ENG.pdf

Yesser. (2015a). E-government Program. Retrieved from http://www.yesser.gov.sa/

Yesser. (2015b). E-government Program. Retrieved from http://yesser.gov.sa

\section{Appendix A}




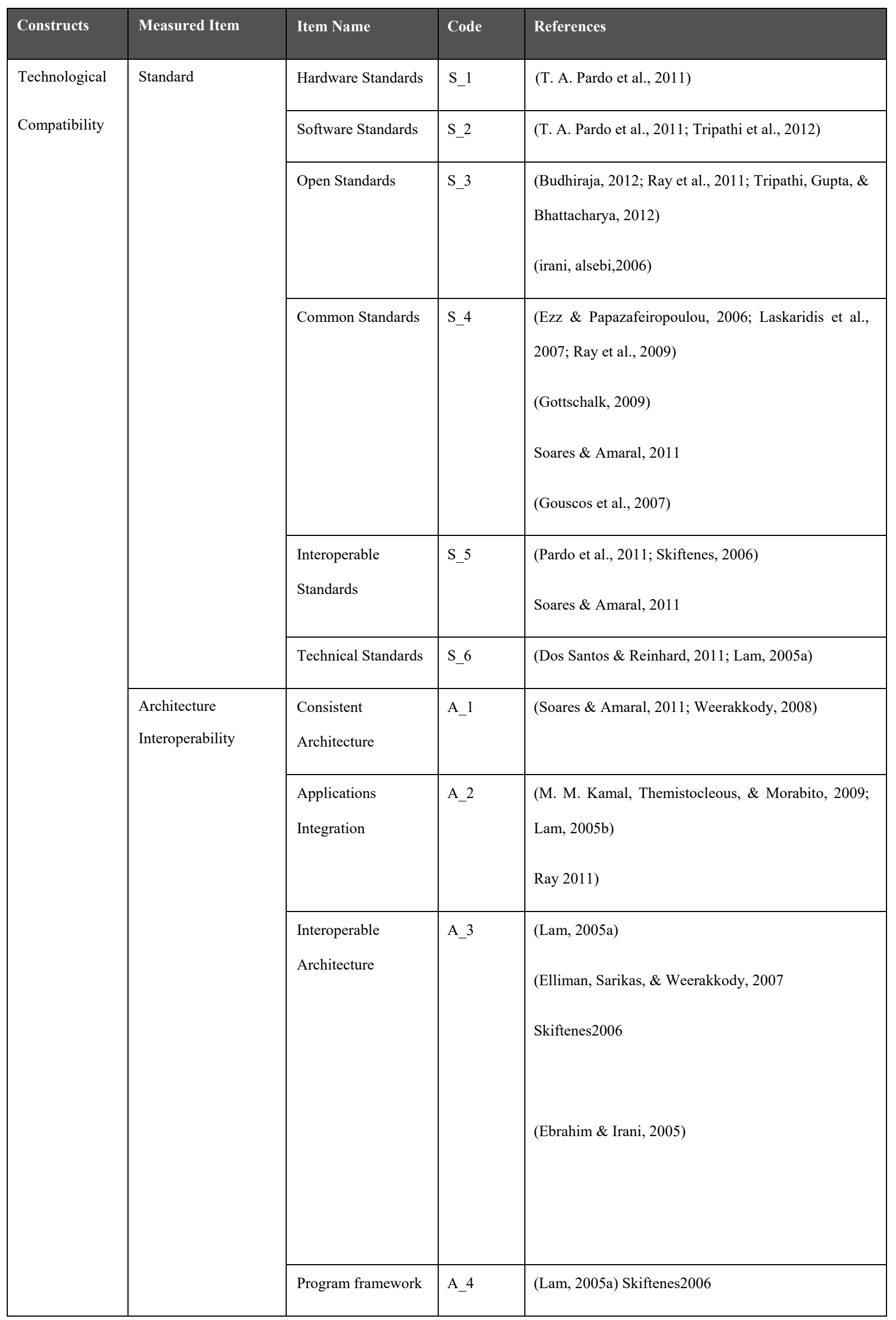




\begin{tabular}{|c|c|c|c|}
\hline & Platforms & A_5 & $\begin{array}{l}\text { (Garlan, Allen, \& Ockerbloom, 1995; Gottschalk, } \\
\text { 2009b; Hreño, Bednár, Furdík, \& Sabol, 2011) } \\
\text { Skiftenes } 2006\end{array}$ \\
\hline \multirow[t]{4}{*}{ Data requirement } & Data Ownership & D_1 & $\begin{array}{l}\text { (Lam, 2005a; Laskaridis et al., 2007; Ray et al., 2009) } \\
\text { Landsbergen Jr \& Wolken Jr, } 2001\end{array}$ \\
\hline & Data Legislations & D_2 & $\begin{array}{l}\text { (Dos Santos \& Reinhard, 2011; Lam, 2005a; } \\
\text { Laskaridis et al., 2007) Weerakkody,2008 }\end{array}$ \\
\hline & Data Monitoring & D_3 & $\begin{array}{l}\text { (Lam, 2005a; Laskaridis et al., 2007; Tripathi et al., } \\
\text { 2012) }\end{array}$ \\
\hline & Data Standard & D_4 & $\begin{array}{l}\text { (Herbert \& Ralf, 2009; Kubicek, Cimander, \& Scholl, } \\
\text { 2011; Lam, 2005a; Landsbergen Jr \& Wolken Jr, } \\
\text { 2001; Pardo et al., 2011) }\end{array}$ \\
\hline \multirow[t]{4}{*}{ Back Systems } & $\begin{array}{l}\text { Business Process of } \\
\text { Back systems }\end{array}$ & BA_1 & $\begin{array}{l}\text { (Decoster \& Zwicker, 2009; Elliman, Sarikas, \& } \\
\text { Weerakkody, 2007; Weerakkody, 2008) }\end{array}$ \\
\hline & $\begin{array}{l}\text { Integration between } \\
\text { back systems }\end{array}$ & BA_2 & $\begin{array}{l}\text { (Herbert \& Ralf, 2009; Klischewski \& Scholl, 2006; } \\
\text { Ray et al., 2011; Tripathi et al., 2013) Weerakkody, } \\
\text { 2008) } \\
\text { (M. M. Kamal, Themistocleous, \& Morabito, } 2009 \\
\text { (Elnaghi, AlShawi, Weerakkody, \& Aziz, } 2009 \\
\text { Gottschalk, 2009b } \\
\text { (irani, alsebi,2006) }\end{array}$ \\
\hline & $\begin{array}{l}\text { Governance of back } \\
\text { systems }\end{array}$ & BA_3 & $\begin{array}{l}\text { (Gottschalk, 2009b; Herbert \& Ralf, 2009) (Bekkers, } \\
2005\end{array}$ \\
\hline & $\begin{array}{l}\text { Back systems } \\
\text { Legacy }\end{array}$ & BA_4 & $\begin{array}{l}\text { (Elliman et al., 2007; Ezz \& Papazafeiropoulou, 2006; } \\
\text { Herbert \& Ralf, 2009; Lam, 2005a; Pardo et al., 2011; } \\
\text { Themistocleous et al., 2005) Weerakkody, } 2008 \\
\text { Skiftenes } 2006 \\
\text { (Ebrahim \& Irani, 2005) }\end{array}$ \\
\hline
\end{tabular}




\begin{tabular}{|c|c|c|c|c|}
\hline \multirow[t]{8}{*}{$\begin{array}{l}\text { Organizational } \\
\text { Compatability }\end{array}$} & \multirow[t]{4}{*}{$\begin{array}{l}\text { Technical staff } \\
\text { Technical staff }\end{array}$} & Staff Resistance & ST_1 & $\begin{array}{l}\text { (Janssen \& Cresswell, 2005) Weerakkody, } 2008 \\
\text { (joia,2004) }\end{array}$ \\
\hline & & Staff Training & ST_2 & $\begin{array}{l}\text { (Heeks, 1999; Lam, 2005a; Malinauskienè, 2013; } \\
\text { Moon, 2002; Tat-Kei Ho, 2002; Valdés et al., 2011) } \\
\text { Themistocleous } 2005 \\
\text { Malinauskienè, 2013) } \\
\text { (Ebrahim \& Irani, 2005) } \\
\text { (joia,2004) }\end{array}$ \\
\hline & & Staff Availability & ST_3 & $\begin{array}{l}\text { (Dos Santos \& Reinhard, 2011; M. Kamal \& } \\
\text { Alsudairi, 2009; Pardo et al., 2011; Soares \& Amaral, } \\
\text { 2011; Tripathi et al., 2013) } \\
\text { (irani, alsebi,2006) }\end{array}$ \\
\hline & & In house staff & ST_4 & $\begin{array}{l}\text { (Altameem et al., 2006; Dos Santos \& Reinhard, 2011; } \\
\text { Elliman et al., 2007; Lam, 2005a; Weerakkody, 2008) }\end{array}$ \\
\hline & \multirow[t]{4}{*}{ Organisation } & $\begin{array}{l}\text { Update Organisation } \\
\text { Structure }\end{array}$ & STR_1 & $\begin{array}{l}\text { (Abramowicz, Bassara，Wisniewski, \& Zebrowski, } \\
\text { 2008; Decoster \& Zwicker, 2009; Lam, 2005a) }\end{array}$ \\
\hline & & $\begin{array}{l}\text { Suitable } \\
\text { Organisation } \\
\text { Structure }\end{array}$ & STR_2 & $\begin{array}{l}\text { (Decoster \& Zwicker, 2009; Pardo et al., 2011; } \\
\text { Weerakkody, 2008) }\end{array}$ \\
\hline & & $\begin{array}{l}\text { Bureaucracy of } \\
\text { Organisation } \\
\text { Structure }\end{array}$ & STR_3 & $\begin{array}{l}\text { (Janssen \& Cresswell, 2005; M. Kamal et al., 2011; } \\
\text { Malinauskiené, 2013) Weerakkody, } 2008\end{array}$ \\
\hline & & $\begin{array}{l}\text { Organisation } \\
\text { Structure }\end{array}$ & STR_4 & $\begin{array}{l}\text { (Decoster \& Zwicker, 2009; Janssen et al., 2011) } \\
\text { (Ebrahim \& Irani, 2005) }\end{array}$ \\
\hline
\end{tabular}




\begin{tabular}{|c|c|c|c|c|}
\hline & & Fragmentation & & \\
\hline & \multirow[t]{6}{*}{$\begin{array}{l}\text { Business Process } \\
\text { Management(BPM) }\end{array}$} & $\begin{array}{l}\text { Business Process } \\
\text { Integration }\end{array}$ & BU_1 & $\begin{array}{l}\text { (Michael Hammer \& Champy, 1994) } \\
\text { (irani,2007) }\end{array}$ \\
\hline & & $\begin{array}{l}\text { Business Process } \\
\text { Training }\end{array}$ & BU_2 & $\begin{array}{l}\text { (Davenport, 2013; Grover, Jeong, Kettinger, \& Teng, } \\
\text { 1995) } \\
\text { Weerakkody, } 2008 \\
\text { Themistocleous et al., 2005) }\end{array}$ \\
\hline & & $\begin{array}{l}\text { Business Process } \\
\text { Coordination }\end{array}$ & BU_3 & $\begin{array}{l}\text { (Al-Rashidi, 2013; Davenport, 2013; Grover et al., } \\
\text { 1995; Herbert \& Ralf, 2009; Laskaridis et al., 2007) } \\
\text { Weerakkody, } 2008\end{array}$ \\
\hline & & $\begin{array}{l}\text { Business Process } \\
\text { Documentation }\end{array}$ & BU_4 & (Davenport, 2013; Müller, Tilley, \& Wong, 1993) \\
\hline & & $\begin{array}{l}\text { Business Process } \\
\text { Standard }\end{array}$ & BU_5 & $\begin{array}{l}\text { (Davenport, 2013; Feuerlicht \& Cunek, 2011; Grover } \\
\text { et al., 1995; Hellman, 2010; Müller et al., 1993) } \\
\text { (T. A. Pardo et al., 2011) }\end{array}$ \\
\hline & & $\begin{array}{l}\text { Business Process } \\
\text { Expertise }\end{array}$ & BU_6 & $\begin{array}{l}\text { (Davidson, 1993; Grover et al., 1995; Hellman, 2010; } \\
\text { Hoffman, 1997) }\end{array}$ \\
\hline \multirow[t]{5}{*}{ Governance } & \multirow[t]{4}{*}{ Fund } & Fund Amount & F_1 & $\begin{array}{l}\text { (Dos Santos \& Reinhard, 2011; Elliman et al., 2007; } \\
\text { Huang \& Bwoma, 2003; Ray et al., 2009; Tripathi et } \\
\text { al., 2013; Weerakkody, 2008) }\end{array}$ \\
\hline & & $\begin{array}{l}\text { Measurement } \\
\text { mechanism }\end{array}$ & F_2 & $\begin{array}{l}\text { (H. J. Scholl \& Klischewski, 2007; Soares \& Amaral, } \\
\text { 2011) Hellman, } 2010\end{array}$ \\
\hline & & Fund Management & F_3 & $\begin{array}{l}\text { (Landsbergen Jr \& Wolken Jr, 2001; Ray et al., 2009; } \\
\text { H. J. Scholl \& Klischewski, 2007) Hellman, } 2010\end{array}$ \\
\hline & & Fund Controlling & F_4 & $\begin{array}{l}\text { (Klischewski \& Scholl, 2006; Pardo et al., 2011; H. J. } \\
\text { Scholl \& Klischewski, 2007) Hellman, } 2010\end{array}$ \\
\hline & Strategy & e-Gov strategy & STA_1 & (Dos Santos \& Reinhard, 2011; Ray et al., 2011) \\
\hline
\end{tabular}




\begin{tabular}{|c|c|c|c|}
\hline \multirow[t]{9}{*}{ Regulations } & & & (Ebrahim \& Irani, 2005) \\
\hline & $\begin{array}{l}\text { Strategy } \\
\text { Commitment }\end{array}$ & STA_2 & (Lam, 2005a) \\
\hline & Strategy Plan & STA_3 & $\begin{array}{l}\text { (Lam, 2005a; Malinauskienė, 2013) } \\
\text { (Tripathi, 2013) }\end{array}$ \\
\hline & Strategy Goal & STA_4 & $\begin{array}{l}\text { (Lam, 2005a; Pardo et al., 2011; Soares \& Amaral, } \\
\text { 2011; Tripathi et al., 2013) }\end{array}$ \\
\hline & Strategy Vision & STA_5 & (Lam, 2005a) \\
\hline & Clear regulations & LE_1 & $\begin{array}{l}\text { (Janssen \& Scholl, 2007; Pardo et al., 2011; Soares \& } \\
\text { Amaral, 2011) Skiftenes2006 }\end{array}$ \\
\hline & Update regulations & LE_2 & $\begin{array}{l}\text { (Janssen et al., 2011; Janssen \& Scholl, 2007; Lam, } \\
\text { 2005a; Pardo et al., 2011) }\end{array}$ \\
\hline & Best practice & LE_3 & $\begin{array}{l}\text { (Decoster \& Zwicker, 2009; Hellman, 2010; Lam, } \\
\text { 2005a) }\end{array}$ \\
\hline & National plan & LE_4 & $\begin{array}{l}\text { (Decoster \& Zwicker, 2009; Hellman, 2010; Lam, } \\
\text { 2005a; Lampathaki, Kroustalias, Koussouris, } \\
\text { Charalabidis, \& Psarras, 2010) Soares \& Amaral, } 2011\end{array}$ \\
\hline \multirow[t]{5}{*}{ Leadership } & Leaders Support & L_1 & $\begin{array}{l}\text { (Klischewski \& Scholl, 2006; Lam, 2005a; Luk, 2009; } \\
\text { Pardo et al., 2011; Tripathi et al., 2013) (irani,2007) }\end{array}$ \\
\hline & Strong leader & L_2 & $\begin{array}{l}\text { (Bekkers, 2005; Hossan, Habib, \& Kushchu, 2006; } \\
\text { Luk, 2009; Pardo et al., 2011) }\end{array}$ \\
\hline & Leaders Cooperation & L_3 & $\begin{array}{l}\text { (Hellman, 2010; Luk, 2009; Ray et al., 2009; Soares } \\
\text { \& Amaral, 2011) }\end{array}$ \\
\hline & Leader Style & L_4 & $\begin{array}{l}\text { (Elnaghi, AlShawi, Weerakkody, \& Aziz, 2009; Luk, } \\
\text { 2009; Malinauskienè, 2013; Pardo \& Burke, 2008a; } \\
\text { Pardo et al., 2011; H. J. Scholl \& Klischewski, 2007) }\end{array}$ \\
\hline & Top leader & L_5 & $\begin{array}{l}\text { (Luk, 2009) Weerakkody, 2008) Soares \& Amaral, } \\
2011\end{array}$ \\
\hline
\end{tabular}




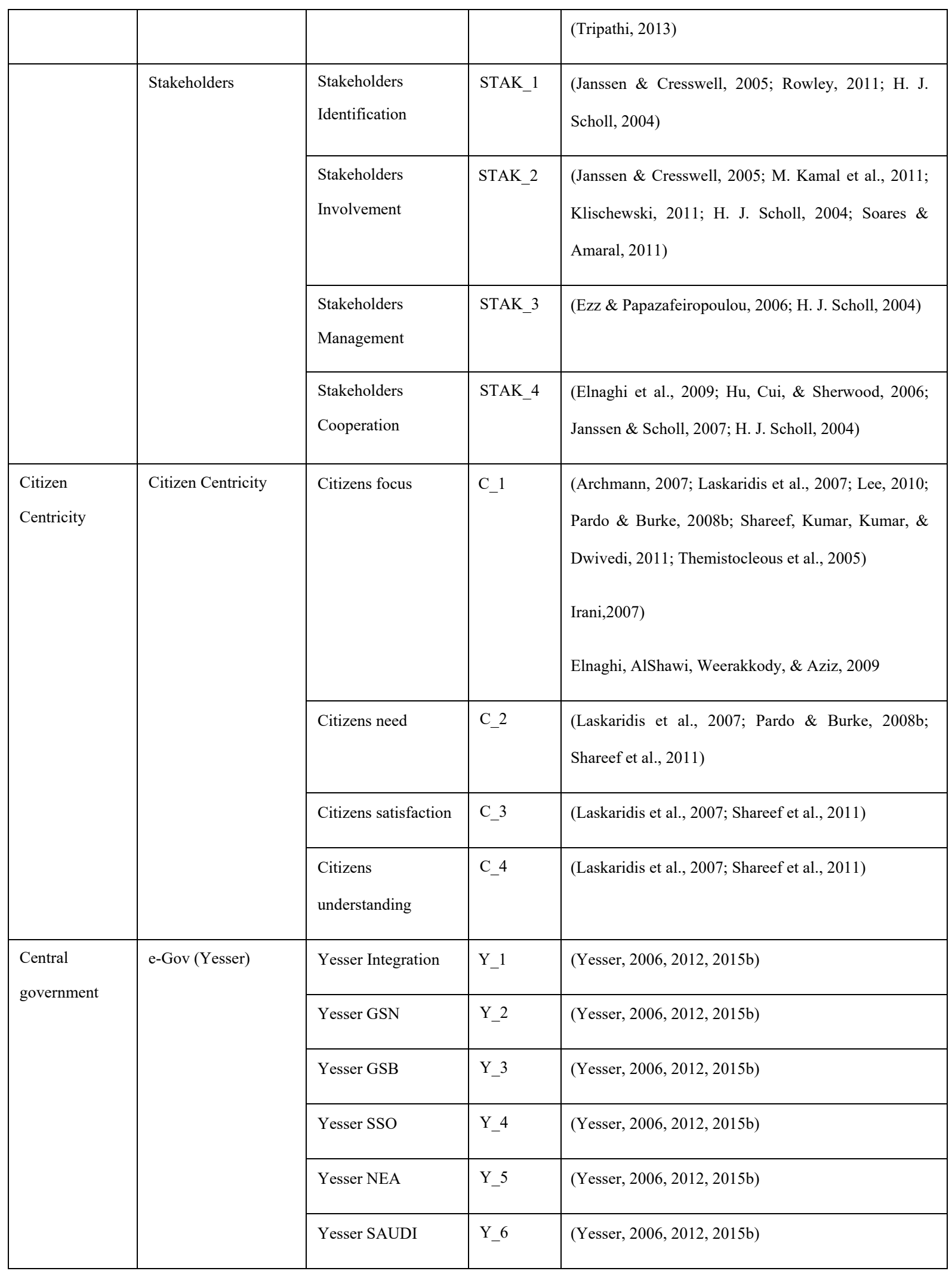

\section{Copyrights}

Copyright for this article is retained by the author(s), with first publication rights granted to the journal.

This is an open-access article distributed under the terms and conditions of the Creative Commons Attribution license (http://creativecommons.org/licenses/by/4.0/). 